\title{
CLINICAL IMPACT OF SENTINEL LYMPH NODE BIOPSY AFTER NEOADJUVANT TREATMENT IN BREAST CANCER PATIENTS WITH INITIALLY INVOLVED AXILLARY LYMPH NODES; SINGLE-CENTER EXPERIENCE- PRELIMINARY ANALYSIS
}

\author{
ANA CAR PETERKO ${ }^{1}$, MANUELA AVIROVIĆ ${ }^{2}$ PETRA VALKOVIĆ ZUJIĆ ${ }^{3}$, \\ INGRID BELAC LOVASIĆ ${ }^{4}$ and FRANJO LOVASIĆ ${ }^{1}$ \\ ${ }^{1}$ Department of General Surgery and Surgical Oncology, Clinical Hospital Center Rijeka, Rijeka, Croatia; \\ ${ }^{2}$ Faculty of Medicine, Department of General Pathology and Pathologic Anatomy, University of Rijeka, \\ Rijeka, Croatia; \\ ${ }^{3}$ Department of Radiology, Clinical Hospital Center Rijeka, Rijeka, Croatia; \\ ${ }^{4}$ Department of Radiotherapy and Oncology, Clinical Hospital Center Rijeka, Rijeka, Croatia
}

\section{Summary}

Introduction: After the consensus conference in St. Gallen and updated NCCN guidelines, we started doing sentinel lymph node biopsy (SLNB) in May 2017, for breast cancer patients who achieve clinical axillary remission following neoadjuvant treatment. This study's primary goal was to evaluate the clinical impact of SLNB after neoadjuvant therapy in the group mentioned above.

Methods: We retrospectively analyzed all neoadjuvant breast cancer patients from May 2016 until May 2018 at Clinical Hospital Center Rijeka. Our preliminary results recorded the appearance of locoregional and distant recurrence.

Results: From 65 patients involved in this analysis, 48 patients were node-positive at the time of diagnosis, and $45.83 \%$ among those achieved complete pathological axillary remission. After the first postoperative year, there were no locoregional relapses nor statistically significant differences in the prevalence of distant recurrences, regardless of the extent of surgical procedure. However, results showed higher rates of locoregional and distant relapse for the group of patients that did not attain complete axillary remission.

Conclusion: SLNB is a reliable alternative to ALND for locoregional and overall disease control for breast cancer patients who achieve complete clinical axillary remission after preoperative systemic treatment. The clinical axillary lymph node status, after neoadjuvant therapy, is a more relevant prognostic factor than the clinical axillary lymph node status at the beginning of the treatment.

KEYWORDS: sentinel lymph node biopsy, neoadjuvant treatment, recurrence

\section{INTRODUCTION}

The idea of sentinel lymph node biopsy is present in literature data from 1951 (1). Although

Corresponding author: Ana Car Peterko, Department of General Surgery and Surgical Oncology, Clinical Hospital Center Rijeka, Krešimirova 42, 51000 Rijeka, Croatia.

e-mail: ana.car.peterko@uniri.hr trials from the late seventies confirmed that there is no survival benefit from axillary lymph node dissection (ALND) in early-stage breast cancer patients with clinically negative axilla (2), merely at the end of the last century the concept of intraoperative detection and biopsy of sentinel lymph node was eventually accepted in the breast cancer surgery $(3,4)$. In a short period, sentinel lymph 
node biopsy (SLNB) became the gold standard of axillary management for early-stage breast cancer (5-9).

Initially contraindicated after neoadjuvant systemic treatment (NAST), SLNB has been recently accepted as a reliable option in this setting, even for those patients with clinically involved axilla before NAST that shifts to clinically negative after treatment (10-17). In Clinical Hospital Center (CHC) Rijeka, SLNB was introduced as standard care for early-stage breast cancer since 2003, and from May 2017, we used the procedure for all patients after NAST, who met the criteria.

\section{PATIENTS AND METHODS}

This retrospective analysis captures all female breast cancer patients (20 to 80 years old), surgically treated after NAST in CHC Rijeka (from May 2016 until May 2018; one year before and one year after SLNB after NAST entered the clinical practice). We recorded the prevalence of locoregional and distant recurrences after the first postoperative year.

Exclusion criteria for the analysis were patients with a history of bilateral, inflammatory, or T4 stage breast cancer, and M1 stage at the time of the diagnosis. We analyzed the data from the integrated electronical records of CHC Rijeka with the approval of the Ethics Committee of Clinical Hospital Center Rijeka. The protocol of this trial was registered and publicly available at www.clinicaltrials.gov, ID: NCT03833960

For statistical calculations, we used the online statistical analysis software MedCalc.net. We considered results statistically significant when $\mathrm{p}=0.05$.

Clinical criteria defined metastatic axillary involvement: ultrasound and/or magnetic and/or clinically suspected and/or cytologically proven positive axillary lymph node(s).

The regional recurrence is the postoperative appearance of the disease in the unilateral axillary, supraclavicular and internal mammary lymph nodes, local recurrence is the postoperative appearance of the disease in the unilateral or contralateral breast or thoracic wall, and the distant recurrence as postoperative clinical or radiologic evidence of disease present anywhere else in the body. The progression-free survival is the absence of proof of locoregional and distant recurrence or cancer-related death in the postoperative one-year follow-up period.

Standard NAST, according to AC-T protocol, joined with HER-2 blockage for HER-2 enriched tumors, was followed by surgical procedure. Whether axillary treatment was ALND or SLNB depended on the patient's multidisciplinary reassessment after NAST and the date of surgery (before or after May 2017).

The basis of sentinel lymph node(s) detection was lymphoscintigraphy with $99 \mathrm{mTc}$-labeled nano colloid (Nanocoll®). On the day of the surgery, radiocolloid was injected intradermally in the breast, and preoperative plane scintigraphy was performed after 30 minutes. We use an intraoperative handheld gamma detecting probe (Neoprobe ${ }^{\circledR}$ Gamma Detecting System)to detect sentinel node(s).

All nodes with the activity detected intraoperatively, as well as all clinically suspected lymph nodes (up to 6 nodes), were considered for sentinel nodes and were removed. If more than six nodes removed, it was considered an ALND.

All removed sentinel lymph nodes were intraoperative longitudinally transected on $4 \mathrm{~mm}$ cuts and analyzed by imprint cytology. For all positive or suspected cases, cuts are frozen and histologically examined for the presence or absence of metastasis. Sentinel lymph nodes negative on imprint cytology were transected afterward for hematoxylin and eosin and pan-cytokeratin staining. Therefore, detection of every residual tumor in the lymph node, including Isolated Tumor Cells (ITC), was ensured.

To stage the primary tumor and lymph nodes, we used the 4th edition of WHO TNM classification form 2012 and appendix of AJCC manual for breast cancer staging.

The primary goal of this analysis was to establish the prevalence of early regional, local and distant recurrence rates in a group of breast cancer patients that achieve complete axillary remission after NAST in correlation with the extension of surgical procedure in the axilla (ALND vs. SLNB). Thereby, we evaluated whether SLNB after NAST is a reliable procedure for maintaining the locoregional and overall control of disease in the patients mentioned above. Secondary endpoints of this analysis were the comparison of progressionfree survival rates among a group of patients that 
achieve a complete axillary response and the group of patients that did not, and determination of differences in locoregional and distant recurrence rates among a group of all ypN0 patients and the group of all not-ypN0 patients.

\section{RESULTS}

From May 2016 till May 2018, 95 breast cancer patients underwent NAST, followed by surgery in CHC Rijeka. We excluded 30 patients from the analysis, for a history of metastatic disease, inflammatory, bilateral, and T4 stages of breast cancer. The remaining 65 patients were divided into four groups.

Table 1.

Display all relevant data for the present retrospective analysis

\begin{tabular}{|l|l|l|l|l|}
\hline & Group 1 & Group 2 & Group 3 & Group 4 \\
\hline Group Definition & $\begin{array}{l}\text { cN0, } \\
\text { ypN0 }\end{array}$ & $\begin{array}{l}\text { cN1-3, } \\
\text { ypN0 }\end{array}$ & $\begin{array}{l}\text { cN0, } \\
\text { ypN1-3 }\end{array}$ & $\begin{array}{l}\text { cN1-3, } \\
\text { ypN1-3 }\end{array}$ \\
\hline Number of patients & 13 & 22 & 4 & 26 \\
\hline SLNB (N) & 11 & 9 & $4(+)$ & 0 \\
\hline ALND (N) & 2 & 13 & 4 & 26 \\
\hline $\begin{array}{l}\text { Regional Recurrence } \\
(\mathrm{N})\end{array}$ & 0 & 0 & 0 & 0 \\
\hline Local Recurrence (N) & 0 & 0 & 0 & 3 \\
\hline $\begin{array}{l}\text { Distant Recurrence } \\
(\mathrm{N})\end{array}$ & 0 & 2 & 0 & 7 \\
\hline
\end{tabular}

$\mathrm{cN}=$ clinical status of axillary lymph nodes before NAST

ypN=pathological status of axillary lymph nodes after NAST

From 65 patients, 17 patients $(26.15 \%)$ had clinically negative axilla at the time of diagnosis (Groups 1 and 3), and 48 patients (73.85\%) had clinically positive axilla (Group 2 and 4).

Twenty-three patients had surgery before May 2017 and the rest of 42 patients after that date. Hence, we recorded an increasing trend of NAST for operable tumors ( $82.6 \%$ in one year).

Following NAST, we recorded the complete pathologic axillary remission (ypNo(sn) and ypN0) in 22 patients (Group 2) from those with initially involved axilla (45.83\%). In the first postoperative year, we did not record regional or local recurrence in Group 2 patients, and there was no statistically significant difference in distant recurrence (proportion difference test, $\mathrm{p}=0.79$ ) between them regardless of the extent of surgical procedure (SLNB vs. ALND).

However, statistically, significantly lower prevalence of distant recurrence was observed in ypN0 group of patients compared to a group of patients that did not achieve complete pathologic axillary remission following NAST (proportion difference test, $\mathrm{p}=0.042$ ), and the prevalence of local relapse was at the borderline of the statistical significance (proportion difference test, $\mathrm{p}=0.057$ ).

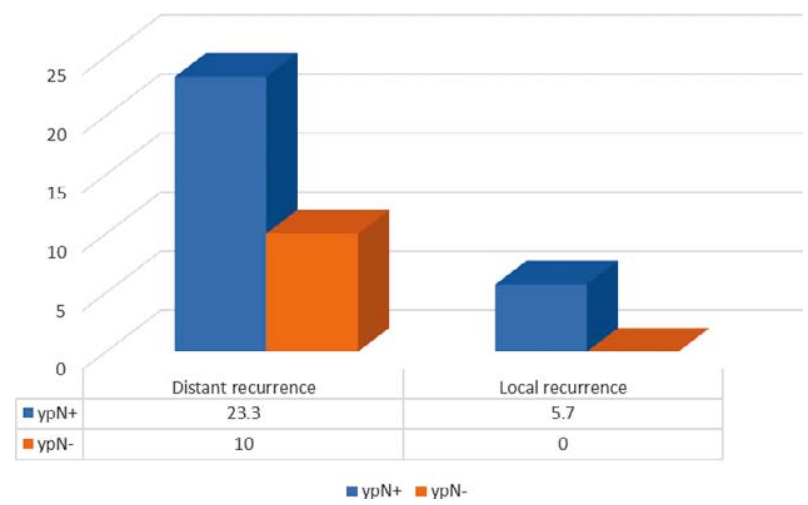

Figure 1. Differences in distant recurrence rate and local recurrence rate between ypN-(ypN0) patients and ypN+(ypN1-3) patients in the first postoperative year

Although progression-free survival rates (calculated by the method of Kaplan Meier) were $90.91 \%$ for group 2 and $69.23 \%$ for group 4 , comparison of progression-free survival curves (Figure 2) did not reach statistical significance in

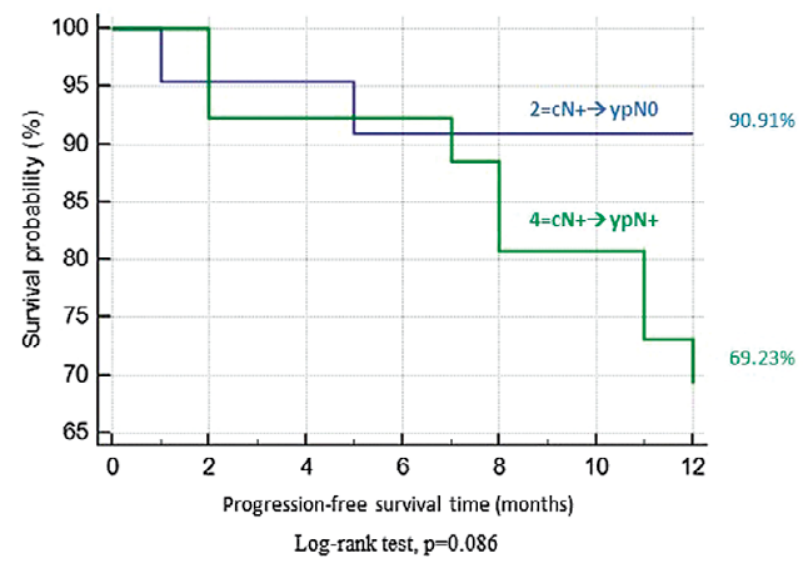

Figure 2. Progression-free survival curves between patients who shift to ypNO by NAST and patients who remain node-positive after NAST. 
merely one year of follow up period (Log-rank test, $\mathrm{p}=0.086$ ).

As expected, more complications were related to the extensiveness of the surgical procedure. Recorded rates of seroma and lymphoedema correlated to the extent of axillary surgery, as shown in figure 3.

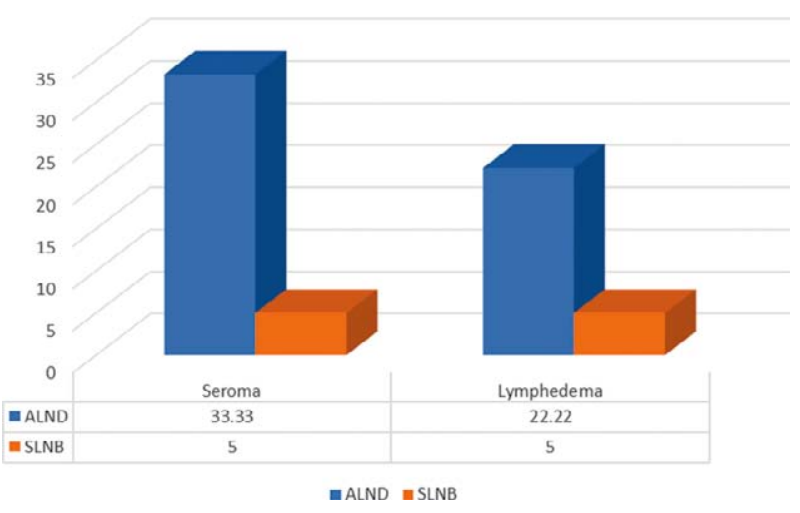

Figure 3. Differences in early and late postoperative complications in correlation with the extent of axillary surgery

\section{DISCUSSION}

We presented our initial experience with SLNB after NAST in initially node-positive breast cancer patients. In 48 patients with initially involved axilla, we had no regional recurrence in the first postoperative year and only 3 cases of local recurrences. In patients that did not achieve pathological complete axillary remission, we performed ALND. In patients with ypN0 stage, no locoregional recurrence and no significant difference in the prevalence of the distant recurrence, regardless of the extent of surgical procedure (SLNB vs. ALND), suggests that SLNB is an adequate alternative to ALND for this group of patients. Our results are in concordance with the previously published Italian retrospective analysis (18) on 147 initially cN1-2 patients converted to $\mathrm{cN} 0$, i.e., 70 sentinels node-negative and 77 sentinels node-positive. All sentinel node-positive patients had ALND. In 5 years, follow up a statistically significant difference in locoregional recurrence was not found between SLNB and ALND group.

Borderline significant differences for local relapse and distant recurrence, as well as the differ- ences of PFS rates, observed among patients with complete axillary response to neoadjuvant treatment and patients that did not achieve complete axillary remission, imply that node status after NAST is far more relevant prognostic factor than node status at the beginning of treatment. We strongly believe that with the larger sample size and the more extended postoperative follow-up period, these differences would overcome borderline significance and become statistically significant.

Upon the idea of utilization SLNB within axillary surgery for early breast cancer in $1994(4,5)$ through the implementation of the method in clinical practice in 2003 in CHC Rijeka, the indications for SLNB are extended far beyond axillary management of early breast cancer. They have become a method of choice for the axillary approach in the majority of breast cancer patients after NAST, who achieve complete clinically axillary remission.

Year after year, we witness an increasing trend of NAST application for operable breast cancer to reduce the extent of surgery, improve the quality of life by reducing the complications rate of lymphoedema and seroma. Because $45 \%$ of patients with initially positive axillary lymph node(s) shift to pathologically negative after NAST, ALND has become overtreatment for those patients. Standardization of the method improved an initially wide range of identification rates and false-negative results. The biopsy of at least three sentinel nodes, marking positive node before NAST and biopsy of a marked node during the surgical procedure, preoperative ultrasound axillary reevaluation, using dual tracer and using the IHC for detecting metastasis in nodes) $(19,20,21)$ introduced SLNB in practice even in this setting. After consensus in St. Gallen (22) and modification of NCCN guidelines in 2017 (23), SLNB after NAST we also introduced in CHC Rijeka. In the beginning, we did not use a dual tracer. We did not mark and biopsy initially positive nodes either, our observations and first clinical experiences indicate that SLNB is not inferior to ALND in this setting for maintaining both locoregional and overall control of disease in initially node-positive patients that achieved complete clinical axillary remission following NAST.

Limitations of this study are a relatively small group of patients, short postoperative follow-up period, and inconsistency of initial cytology proof 
for metastasis in nodes that we classified as positive. Based on these preliminary findings, we initiated a prospective trial in September 2018. (protocol is available at www.clinicaltrials.gov. ID: NCT03719833).

\section{CONCLUSION}

Analysis of one year follow up results of breast cancer patients operated after neoadjuvant systemic therapy in CHC Rijeka from May 2016 until May 2018 showed a significant increasing trend of NAST for operable but locally advanced breast cancer.

In our group of 65 patients, $73.85 \%$ had positive axillary nodes at the time of diagnosis, and $45.83 \%$ achieved complete clinical axillary remission (ypNo/ypNo(sn)).

Observed clinical outcomes in the first postoperative year suggest that SLNB after NAST is a reliable approach, not inferior to ALND for locoregional and overall control of the disease. Furthermore, lymph node status after NAST is a more influential prognostic factor than lymph node status at the beginning of treatment.

Herein we want to point out that by multidisciplinary, individual approach to every patient after NAST and appropriate axillary reevaluation, we probably can omit ALND with its consecutive morbidity in the selected group of patients (in our trial for $45 \%$ of initially node-positive patients) without compromising oncologic principles and without negative impact on clinical outcome. These were preliminary findings and an ongoing prospective trial designed to test these results in a large group of patients (24).

\section{Abbreviations}
NCCN - National Comprehensive Cancer Net- work,
SLNB - sentinel lymph node biopsy,
ALND - axillary lymph node dissection

Acknowledgment: none

Statement of Ethics: This research was conducted ethically following the World Medical Association Declaration of Helsinki and was approved by the Ethics Committee of Clinical Hospital Center Rijeka
Disclosure Statement: The authors have no conflict of interest to declare

Funding Sources: none

Author Contributions: All authors contributed to the conception of work, acquisition, analysis, interpretation of data, and revising the work. All authors give the final approval of this version and agree to be accountable for all aspects of the work.

\section{REFERENCES}

1. Gould EA, Winship T, Philbin PH, Kerr HH. Observations on a "sentinel node" in cancer of the parotid. Cancer. 1960;13:77-78. doi:10.1002/1097-0142(196001/ 02)13:1<77::AID-CNCR2820130114>3.0.CO;2-D.

2. Krag DN, Anderson SJ, Julian TB, Brown AM, Harlow $\mathrm{SP}$, Costantino JP, et al. Sentinel-lymph node resection was compared with conventional axillary-lymph-node dissection in clinically node-negative patients with breast cancer: Overall survival findings from the NSABP B-32 randomized phase 3 trial. Lancet Oncol. 2010;11:927-933. doi:10.1016/S1470-2045(10)70207-2.

3. Krag DN, Weaver DL, Alex JC, Fairbank JT. Surgical resection and radiolocalization of the sentinel lymph node in breast cancer using a gamma probe. Surg Oncol. 1993;2:335-339. doi:10.1016/0960-7404(93)90064-6.

4. Giuliano AE. Mapping a Pathway for Axillary Staging. Arch Surg. 1999;134:195-199. doi:10.1001/archsurg. 134.2.195.

5. Veronesi U, Paganelli G, Viale G, Luini A, Zurrida S, Galimberti V, et al. A randomized comparison of sentinel-node biopsy with routine axillary dissection in breast cancer. N Engl J Med. 2003;349:546-553. doi: 10.1056/NEJMoa012782.

6. Mansel RE, Fallowfield L, Kissin M, Goyal A, Newcombe RG, Dixon JM, et al. Randomized multicenter trial of sentinel node biopsy versus standard axillary treatment in operable breast cancer: The ALMANAC trial. J Natl Cancer Inst. 2006;98:599-609. doi:10.1093/ jnci/djj158.

7. Zavagno G, De Salvo GL, Scalco G, Bozza F, Barutta L, Del Bianco $P$, et al. A randomized clinical trial on sentinel lymph node biopsy versus axillary lymph node dissection in breast cancer: Results of the sentinella/ GIVOM trial. Ann Surg. 2008;247: 207-213 doi:10.1097/ SLA.0b013e31812e6a73.

8. Gill G. Sentinel-lymph-node-based management or routine axillary clearance? One-year outcomes of sentinel node biopsy versus axillary clearance (SNAC): A randomized controlled surgical trial. Ann Surg Oncol. 2009;216:266-275. doi:10.1245/s10434-008-0229-z.

9. Canavese G, Catturich A, Vecchio C, Tomei D, Gipponi $M$, Villa $G$, et al. Sentinel node biopsy compared with complete axillary dissection for staging early breast cancer with clinically negative lymph nodes: 
Results of randomized trial. Ann Oncol. 2009;20:10011007. doi:10.1093/annonc/mdn746.

10. Tan VKM, Goh BKP, Fook-Chong S, Khin LW, Wong WK, Yong WS. The feasibility and accuracy of sentinel lymph node biopsy in clinically node-negative patients after neoadjuvant chemotherapy for breast cancer - A systematic review and meta-analysis. J Surg Oncol. 2011;104:97-103. doi:10.1002/jso.21911.

11. Van Nijnatten TJA, Schipper RJ, Lobbes MBI, Nelemans PJ, Beets-Tan RGH, Smidt ML. The diagnostic performance of sentinel lymph node biopsy in pathologically confirmed node positive breast cancer patients after neoadjuvant systemic therapy: A systematic review and meta-analysis. Eur J Surg Oncol. 2015;41:1278-1287. doi:10.1016/j.ejso.2015.07.020.

12. Hunt KK, Yi M, Mittendorf EA, Guerrero C, Babiera G V., Bedrosian I, et al. Sentinel lymph node surgery after neoadjuvant chemotherapy is accurate and reduces the need for axillary dissection in breast cancer patients. Ann Surg. 2009;250(4):558-566. doi:10.1097/SLA $.0 \mathrm{~b} 013 \mathrm{e} 3181 \mathrm{~b} 8 \mathrm{fd} 5 \mathrm{e}$.

13. Newman EA, Sabel MS, Nees A V., Schott A, Diehl KM, Cimmino VM, et al. Sentinel lymph node biopsy performed after neoadjuvant chemotherapy is accurate in patients with documented node-positive breast cancer at presentation. Ann Surg Oncol. 2007;14(10): 2946-2952. doi:10.1245/s10434-007-9403-y.

14. Canavese G, Dozin B, Vecchio C, Tomei D, Villa G, Carli F, et al. Accuracy of sentinel lymph node biopsy after neo-adjuvant chemotherapy in patients with locally advanced breast cancer and clinically positive axillary nodes. Eur J Surg Oncol. 2011;37(8):688-694. doi:10.1016/j.ejso.2011.05.012.

15. Xing Y, Foy M, Cox DD, Kuerer HM, Hunt KK, Cormier JN. Meta-analysis of sentinel lymph node biopsy after preoperative chemotherapy in patients with breast cancer. Br J Surg 2006;93(5):539-546. doi: 10.1002/bjs.5209.

16. Kelly AM, Dwamena B, Cronin P, Carlos RC. Breast Cancer. Sentinel Node Identification and Classification after Neoadjuvant Chemotherapy-Systematic Review and Meta Analysis. Acad Radiol. 2009;16(5):551563. doi:10.1016/j.acra.2009.01.026.

17. Corso G, Grana CM, Gilardi L, Baio SM, De Lorenzo $\mathrm{D}$, Maisonneuve $\mathrm{P}$, et al. Feasibility of lymphoscintig- raphy for sentinel node identification after neo-adjuvant therapy. Ann Ital Chir. 2017;88:201-205.

18. Galimberti V, Ribeiro Fontana SK, Maisonneuve P et al. Sentinel node biopsy after neoadjuvant treatment in breast cancer: five-year follow-up of patients with clinically node-negative or node-positive disease before treatment. Eur J Surg Oncol. 2016;42(3):361-368. DOI:https://doi.org/10.1016/j.ejso.2015.11.019

19. Boughey JC, Suman VJ, Mittendorf EA, Ahrendt GM, Wilke LG, Taback B, et al. Sentinel lymph node surgery after neoadjuvant chemotherapy in patients with node-positive breast cancer: The ACOSOG Z1071 (alliance) clinical trial. JAMA. 2013;310(14):1455-1461. doi: 10.1001/jama.2013.278932.

20. Boileau JF, Poirier B, Basik M, Holloway CMB, Gaboury L, Sideris L, et al. Sentinel node biopsy after neoadjuvant chemotherapy in biopsy-proven nodepositive breast cancer: The SN FNAC study. J Clin Oncol. 2015;33(3):258-264. doi:10.1200/JCO.2014.55.7827.

21. Boughey JC, Ballman K V., Hunt KK, McCall LM, Mittendorf EA, Ahrendt GM, et al. Axillary ultrasound after neoadjuvant chemotherapy and its impact on sentinel lymph node surgery: Results from the American college of surgeons oncology group Z1071 Trial (Alliance). J Clin Oncol. 2015;33(30):3386-3393. doi: 10.1200/JCO.2014.57.8401.

22. Curigliano G, Burstein HJ, Winer EP, Gnant M, Dubsky P, Loibl S, et al. De-escalating and escalating treatments for early-stage breast cancer: The St. Gallen International Expert Consensus Conference on the Primary Therapy of Early Breast Cancer. Ann Oncol. 2017;28:1700-1712. doi:10.1093/annonc/mdx308.

23. Gnant M, Harbeck N, Thomssen C. St. Gallen/Vienna 2017: A Brief Summary of the Consensus Discussion about Escalation and De-Escalation of Primary Breast Cancer Treatment. Breast Care. 2017;12(2):102-107. doi:10.1159/000475698.

24. Car Peterko A, Avirović M, Mance D, Valković Zujić P, Belac Lovasić I, Lovasić F. Clinical impact of sentinel lymph node biopsy after neoadjuvant systemic treatment in luminal B, HER-2 positive and triple-negative breast cancer patients with initially involved axillary lymph node(s); protocol for prospective, non-randomised, observational clinical trial. Lib Oncol. 2019; 47(1):29-35. doi:10.20471/LO.2019.47.01.06 


\section{Sažetak \\ UTJECAJ BIOPSIJE SENTINEL LIMFNOG ČVORA \\ NAKON NEOADJUVANTNOG SISTEMSKOG LIJEČENJA NA KLINIČKI ISHOD BOLESNICA OBOLJELIH OD KARCINOMA DOJKE SA INICIJALNO POZITIVNOM AKSILOM}

\section{A. Car Peterko, M. Avirović, P. Valković Zujić, I. Belac Lovasić and F. Lovasić}

Uvod: Nakon konsenzusa postignutog na konferenciji u St. Gallen-u i revizije NCCN-ovih smjernica za liječenje karcinoma dojke, u svibnju 2017. godine u Kliničkom Bolničkom Centru Rijeka, biopsija sentinel limfnog čvora uvedena je u kliničku praksu kirurškog liječenja bolesnica oboljelih od karcinoma dojke koje su neoadjuvantnim liječenjem postigle kliničku remisiju u aksili. Primarni cilj ovog istraživanja bila je evaluacija kliničkog utjecaja metode u gore navedenoj skupini pacijentica.

Metode: U ovu retrospektivnu analizu uključene su sve bolesnice oboljele od karcinoma dojke, liječene u KBC Rijeka u period od svibnja 2016. do svibnja 2018., kod kojih je preoperativno provedeno sistemsko onkološko liječenje. U prvoj postoperativnoj godini praćena je pojava lokoregionalnog i sistemskog recidiva.

Rezultati: Četrdeset i osam od sveukupno 65 bolesnica uključenih u analizu prezentiralo se je sa pozitivnim aksilarnim limfnim čvorovima u vrijeme postavljanja dijagnoze, od kojih je $45.83 \%$ postiglo kompletnu patološku aksilarnu remisiju. Kod ove skupine pacijentica u prvoj postoperativnoj godini nije zabilježen niti jedan slučaj lokoregionalnog recidiva, niti statistički značajna razlika u pojavnosti udaljenih metastaza u korelaciji sa opsegom kirurškog zahvata u aksili. Međutim, u komparaciji sa ovom skupinom, kod bolesnica koje nisu postigle kompletnu aksilarnu remisiju zabilježene su više stope i lokoregionalnog i distalnog recidiva. Zaključak: Biopsija sentinel limfnog čvora je pouzdana alternativa aksilarnoj disekciji za postizanje lokoregionalne kontrole i kontrole bolesti uopće, kod bolesnica oboljelih od karcinoma dojke koje neoadjuvantnim sistemskim liječenjem postignu kompletnu kliničku aksilarnu remisiju. Odgovor aksilarnih limfnih čvorova na neoadjuvantno liječenje važniji je prognostički čimbenik od statusa limfnih čvorova na početku liječenja.

KLJUČNE RIJEČI: biopsija limfnog čvora čuvara, neoadjuvantna terapija, recidiv 